\title{
Alternative Medicine and Molecular Mechanisms in Chronic Degenerative Diseases
}

\author{
Alma Lorena López Velazquez ${ }^{1}$, María de la Luz Miranda Beltrán², Arturo Panduro ${ }^{3}$, \\ Luis Huacuja Ruiz ${ }^{1}$ \\ ${ }^{1}$ Chronic Degenerative Disease Institute, Centro Universitario de Ciencias de la Salud (CUCS), \\ University of Guadalajara, Guadalajara, México \\ ${ }^{2}$ Biomedical Applications Laboratory, Centro Universitario de los Lagos (CU-Lagos), \\ University of Guadalajara, Lagos de Moreno, México \\ ${ }^{3}$ Molecular Biology in Medicine Laboratory, Fray Antonio Alcalde Hospital, Guadalajara, México \\ E-mail:luhuacu@hotmail.com,allopezvel@hotmail.com \\ Received April 4, 2011; revised April 18, 2011; accepted April 28, 2011
}

\begin{abstract}
Knowledge of healing plants worldwide properties it has-been extensively studied by their biological activities. The increasing number of plant users for healthcare originated the Research Center in Complementary Alternative Medicine, National Institute of Health (NIH) whose primary function is to be alert with a strictly scientific sense about de use of plants as main source of Complementary Alternative Medicine. It is currently about the synergy known that Is achieved on the hepatoprotective, antioxidant and hypoglycaemic activities with mixtures formed by selected plants and combined. These plants are characterized by their content of hidroxyphenolic compounds as cynarin, rosmarinic acid, flavonoids silybin and among others. Actually this kind of herbal preparations are investigated in patients with cirrhosis, type II diabetes mellitus, breast cancer and arthritis diseases. Patients with Chronic Degenerative Diseases are in state of stress and Its metabolism produces free radicals such as superoxide ${ }^{\circ} \mathrm{O}_{2}$, hydroxyl ${ }^{\circ} \mathrm{OH}$ and peroxynitrite highly reactive with unsaturated fatty acids of cell membranes producing lipid peroxidation. The main product of this process is the peroxyl, that when it's reduced forms hydroxiperoxyle its decomposition forms MDA and 4-hidroxialquenal. These substances bind to $\mathrm{R}-\mathrm{SH}_{2}$ of the aminoacids of the proteins and to the thymine of DNA, altering their biological function. Before the treatments with selected and micropulverized plants to patients, it is necessary and required in animal models demonstrate that plants do not produce toxic effects. Using mixtures of plants micropulverized is good choice because these microparticles behave as micro-releasing their constituents with increased activity and bioavailability to target cells so it will be possible to achieve greater power to control their activity and perhaps cure the disease, and provide patients an effective herbal medicine safe, free of toxic effects and low cost.
\end{abstract}

Keywords: Alternative Medicine, Mixture of Plants, Stress, Lipoperoxidatio

\section{Introduction}

Since ancient times man has learned to live with environmental plant and suddenly he realized that some plants had medicinal properties, but some could intoxicate him until provoke the death. He learned to classify and distinguish it of which were harmful and those were medicated, thus becoming the primitive herbalist or chief physician, if, that herbal medicine is as old as the man [1-3]. It is concluded that knowledge about the use of medicinal plants since ancient times, have been transmitted from generation to generation, giving rise to the Traditional Medicine, which has evolved to Herbal Medicine and Scientific Medicine. The first relates to semi-purified herbal products consist of two, three or more compounds whose effects are investigated experimentally and its therapeutic efficacy is proven in clinical studies by medical practice and are employed in the field of scientific medicine is used as an active substance or drug [4-7].

Phytotherapy is the treatment of plants and vegetable substances, and also designating the treatments with the preparations of herbal remedies containing refined vege- 
table ingredients, extracts of plants or parts of them. It has been demonstrated that in general the biological activity of plants is greater when using mixed [6,8-11], in this way they, achieve a positive synergy with the advantage of minimizing any risk of toxicity [6,8] This synergistic effect is even greater when the plants are selected for their biological activity and physico-chemical properties similar.

Currently the use of Traditional Medicine has diversified extensively in the biological activity possessed by plants as antiviral [12-15], antimicrobial [16,17], immunological [18], anticarcinogenic [19,20], contraceptive [5,21] and liver disease [22-24], gastrointestinal [25], ar- thritis [26] and antidiabetic [6,27-29] among others. In the use of Alternative Medicine it is notable that it increases with development, income and younger patients [30,31]. Ernst and col carried out a bibliographic review of treatments used by cancer patients in 26 stages in 13 countries. The authors report certain variation in the use of Alternative Medicine is between $14.2 \%$ to $64 \%$ [31] Figure 1. In Latin America, the countries that stand out as Alternative Medicine users are Brazil, Argentina, and Mexico as revealed by their scientific communications [4] Figure 2.

Due to the increase in users of plants for treating their illnesses by decree in 1999 the Institute of Complementary Alternative Medicine (CAM) at the National

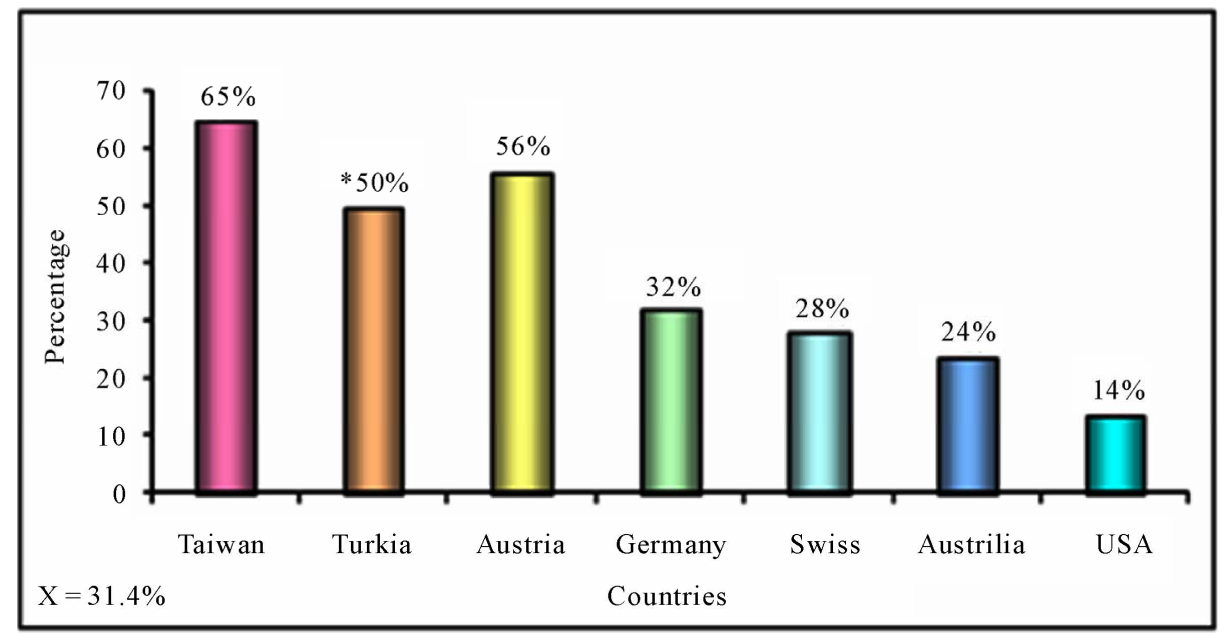

Figure 1. Frequency of patients with cancer patients of MAC users. This figure shows significant variation in the use of MAC by patients with breast cancer, although in the United States showed the lowest percentage of these users, is the country with the greatest number of research projects at different institutes, research centers and universities.

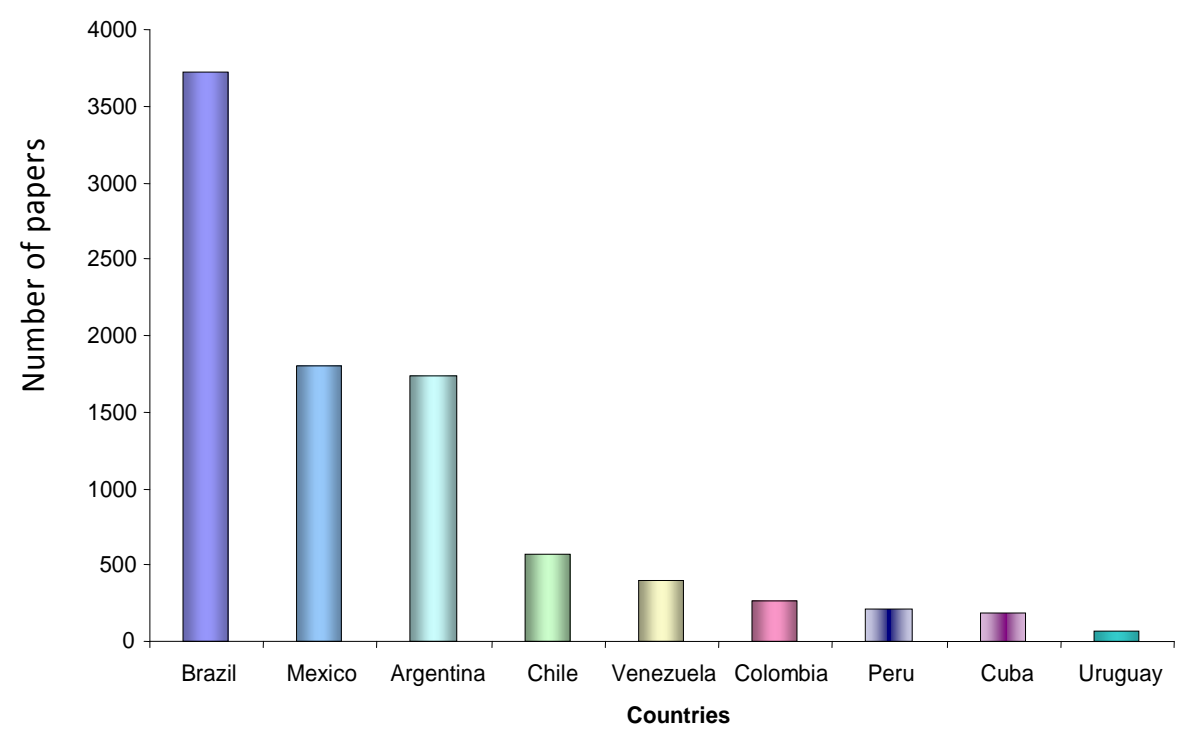

Figure 2. Scientific production plants in selected Latin American countries in the 1984-2004 periods. This figure shows countries with the high scientific production is Brazil and then Mexico and Argentina, the rest of the countries with a difference in their scientific production plants significantly lower. 
Institute of Health (NIH) [19] was established in response to high demand information on CAM became the National Center for Complementary Alternative Medicine (NCCAM) whose primary function is to support research with plants in a rigorous scientific context and provide authoritative information to researchers and the general public. Thus, the real benefits of herbal products are categorized in a higher level of scientific corroboration and validation applied to a wide variety of therapeutic possibilities as in patients suffering from chronic degenerative diseases, fibrosis/cirrhosis, arthritis, cancer and diabetes mellitus type 2, among others, cases in which conventional medicine has reached its limit [32].

It is important to note that the empirical use of herbal preparations involves risk, improper use can pose a public health problem, and the greatest danger is when the plants are use used indiscriminately. In this sense, many people wrongly believe that plants are safe and secure employments are to be of natural origin. There are often in hospitals with poisoning attributed to misuse of the plants, mainly due to the self limitation, lack of plant species used or the dose abuse it is necessary that herbal therapies are prescribed by professionals in the knowledge of plant use and monitor the effectiveness and safety of treatments.

Today herbs are the main source of Complementary Alternative Medicine (CAM), medical groups such theories, attitudes and treatment practices used to counteract the side effects of conventional medicine [33-35]. The patients using this type of medicine are convinced that the treatments are natural, safe and effective, stimulating the immune system, are cheaper, and better control their disease.

The processes of scientific research of plants requires a comprehensive knowledge of them and their chemical and physicochemical characteristics and involved in molecular mechanisms of its activity and then apply methodological and novel therapeutic strategies in order to verify the effectiveness and safety the healing properties of plants. It is important to stress that various molecular mechanisms in the biological activity of several plants have been published with much interest in the control and development of chronic degenerative diseases such as DM2, fibrosis/cirrhosis, cancer, arthritis and obesity [7]. Because plants are the main source of alternative medicine as they are learning mechanisms of its activity, it is very clear trend of acceptance in universities, hospitals and medical centers of the Mexican Institute Social Security (IMSS). In the first International Congress of Integrative Medicine held in Guadalajara in December 2004 officially announced the acceptance of traditional medicine in universities and health centers to help prevent and even cure with allopathic treatments.

It is shown that the greatest future of Complementary
Alternative Medicine is the use of plants combined to form mixtures $[6,11,18,36]$, of course, to try to understand the mechanism of action is required to know the chemical composition and structure of its constituents [11]. It has been described that a different mix of plants and shown to be more effective than single or composite plant just to produce the desired effect, these preparations are commonly used in health care as has been demonstrated by clinical treatments $[8,9,36]$. Their constituents are acting more integrated not only into a specific organ as does an active ingredient or drug but also do so in receptor cells of other tissues involved in disease.

In another context, we investigated different drug eluting systems such as microspheres [37] polymeric micelles $[38,39]$ or nanotubes that release anticancer drugs to tumors in different parts of the body [40,41]. In this sense, the strategy of using mixtures of plants micropulverized is good choice because these microparticles behave as micro-releasing their constituents with greater bioavailability to target cells. This assertion is based on the benefits achieved with the treatments of different mixtures of plants $[6,9,11,18,36,42]$ and to synergize the effect does not produce toxic effects or at least reduced to a minimum. We have shown that such preparations micropulverized selected plants to a particle size of 20 to 200 microns combined in appropriate proportions to form mixtures; these preparations do not produce toxic effects during or at the end of treatment in animal models induced T2DM. In chronically infertile patients has been achieved $100 \%$ restore the quality of semen with the possibility of inducing spontaneous pregnancies what we have achieved with 2 of 8 cases.

Before treatments to patients with multifactorial diseases it is necessary to demonstrate through pharmacological studies in animal models for mixtures of selected plants micropulverized not produce evidence of any signs of toxicity in subchronic 30-day treatment and thus is relevant propose that these preparations are feasible and effective for the control of various diseases.

Using mixtures of plants micropulverized is good choice because these microparticles behave as micro-releasing their constituents with increased activity and bioavailability to target cells so it will be possible to achieve greater power to control their activity and perhaps cure the disease, and provide patients an effective herbal medicine safe, free of toxic effects and low cost.

It is necessary that medical professionals learn more about current therapies of Alternative Medicine Complementary and very respectfully ask their patients whether or not users of some form of Alternative Medicine and thus able to advise their patients on the use of this plants. There is no doubt that plants are an extraordinary remedy of nature because they have a veritable arsenal of poten- 
tially useful biomolecules to develop new effective and safe phytotherapeutic strategies with the possibility of increasing the effectiveness of conventional medicine treatments for chronic diseases mainly degenerative diseases such as fibrosis/cirrhosis, type 2 diabetes, arthritis and breast cancer.

\section{Molecular Mechanisms of Medicine in Multifactorial Diseases}

First, the processes of scientific research on medicinal plants requires a comprehensive knowledge of them, their chemical and physicochemical characteristics and their association with the molecular mechanisms of its activity and then develops and implement innovative methodological strategies in order to try to know molecular level the healing properties of plants described by the Complementary Alternative Medicine. By this approach, there have been reported various mechanisms of activity of many plants with great impact on prevention, development and even cure chronic degenerative diseases. People with any of these diseases, accelerate the excessive production of free radicals and induce non-enzymatic glycation of proteins and peroxidation of polyunsaturated fatty acids in the cell membrane, these processes are involved in the development of DM2 [43] and other diseases such as cirrhosis [22,33]. The close relationship between lipid peroxidation and nonenzymatic glycosylation of proteins suggests that the antidiabetic activity of plants is due to a synergistic effect of antioxidant and antiglycaemic activities as has been recently confirmed by the plant extract rich in saponins very active in inactivation (53.85\% to $91.15 \%)$ of free radicals $[43,44]$.

Plants selected for their hepatoprotective and antioxidant activities are characterized by their content of hidroxiphenolic compounds as flavonoids, carnosol [45], cinarina, boldin [46], rosmarinic acid [22] baicalin and baicalein [18], and brevifolina [14] compounds highly active against free radicals protecting the cell membrane lipoperoxidation. Figure 3. These plants have anticirrhotic and antioxidant activity [8,22,23], stimulate the immune system [18] and against hepatitis B virus [13,14]. It was concluded a study in Wistar rats with liver damage with carbon tetrachloride and treated with the mixture of 7 plants which showed no changes in the cytoarchitecture of the liver parenchyma or biochemical parameters indicative of metabolism such as transaminase, cholesterol, triglycerides, lipoproteins, bilirubin, protein and albumin. These effects produced by mixtures of plants probably do in part by the reaction of the hydroxyl group of the aromatic ring of the constituents of plants against free radicals and preventing lipid peroxidation possibly by inhibiting the activation of stellate cells to cause fibrosis/ cirrhosis.

In the case of DM2, we know that the development of this disease is associated with multiple interacting genetic, environmental and cultural. DM2 patients are under chronic stress very aggressive chemistry that leads to<smiles>[R]c1cc(C2CC(=O)c3ccc(O)cc3O2)ccc1O</smiles><smiles>CC(C)c1cc2c(c(O)c1O)C13CCCC(C)(C)C1CC(O2)C3(C)C</smiles><smiles>O=C1OC2C(=O)CCC2C2C(=O)CCC12</smiles>

Brevifoline<smiles>COC1CC2C(CC1O)CC1C(O)C(O)CC3CCC(C21)N(C)CC3</smiles>

Caffeic acid

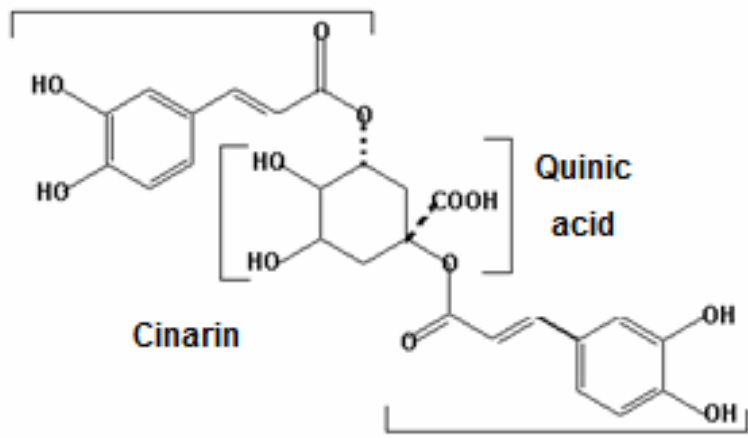

Caffeic acid

Figure 3. Hepatoprotective and antioxidant molecules from plants. 
diabetes to an inability to metabolize glucose (hyperglycemic) and increased lipolysis, which develop a patient glucolipointoxicación insulin resistance (Figure 4). Given this loss of metabolic homeostasis of lipids and carbohydrates, synthetic drugs have been used with hypoglycemic activity but most adverse effects [33-35]. Given these complications has been investigated in experimental animals and humans many plants with hypoglycaemic effect $[6,28,47]$ and has proposed that the hypoglycemic effect of plants occurs through three mechanisms: first, increased insulin secretion, second, increased glucose uptake by muscle and adipose tissue and third, inhibition of glucose absorption from the intestine [7].

The natural juice of Opuntia ficus indica lyophilized showed potent antioxidant, protects chondrocytes from damage from free radicals produced more potent than hyaluronic acid also has antioxidant effects. It is suggested that the increased activity of Opuntia is due to polysaccharides that are more resistant to depolymerization [26]. It is proposed that the greatest future of the MAC is the use of plants combined to form mixtures, of course, to try to understand its mechanism of action is required know the chemical composition and structure of its constituents $[14,36]$ have described different mixtures of plants and shown to be more effective than a single compound to produce the desired effect, these preparations are commonly used common in the healthcare and clinical treatments [8,36]. High correlation was found between the content of compounds such as chlorogenic acid and hidroxifenólicos cinarina with the decrease of transaminases, malondialdehyde and increased flow bile in rats poisoned with carbon tetrachloride [24].

\section{Oxidative Stress}

It is well known that patients suffering from a chronic degenerative disease such as T2DM, fibrosis/cirrhosis, cancer or obesity are in a state of very aggressive peroxidative stress caused by multiple stressors such as infection by viruses or bacteria, compounds toxins, poor diet including psychosocial factors of modern life as it is becoming increasingly difficult to obtain enough satisfactions for a quality life which causes distress, frustration, resentment and consequently a state of stress. In these stressful conditions produced substances nitrogen and oxygen called free radicals and superoxide anions ${ }^{\circ} \mathrm{O}_{2}$,

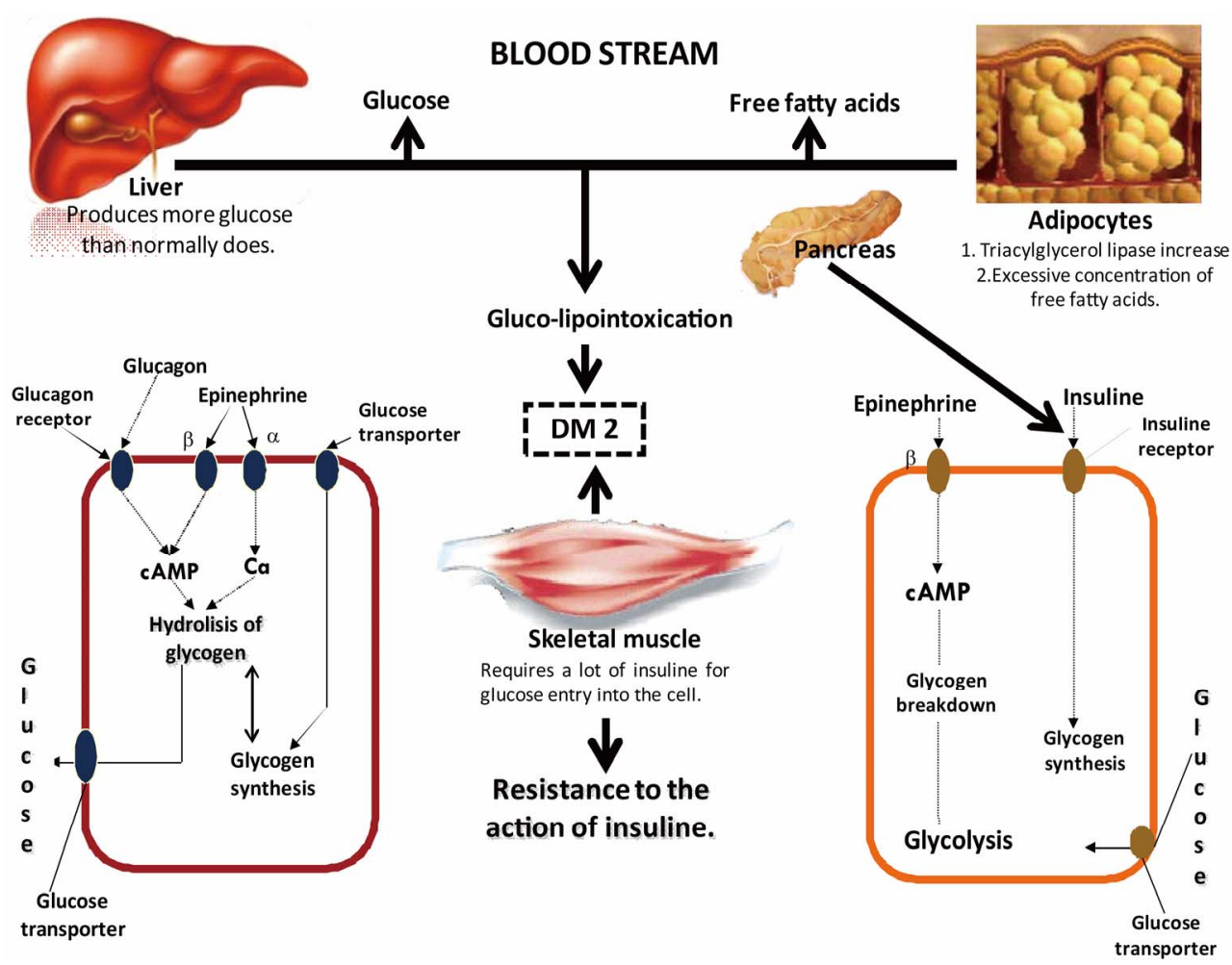

Figure 4. Pathophysiology of Diabetes Mellitus 2. This figure shows the interaction of key actors in the development of DM2, liver, pancreas, adipose tissue and muscle. It is very obvious that the balance between hydrolysis and synthesis of glycogen is altered. Hydrolysis of glycogen in the liver beyond normal so this organ blood exported to high glucose concentrations, an exaggerated adipocyte lipolysis exports high concentrations of free fatty acids, this glucolipointoxicacion makes insulin resistant muscle. In this process a very important part of the insulin receptor in muscle and liver receptors alpha and beta adrenergic and glucagon that facilitate the entry of calcium and cyclic AMP are necessary to preserve the hydrolysis and synthesis of glycogen. 
hydroxyl ${ }^{\circ} \mathrm{OH}$, NO peroxynitrite ${ }^{\circ} \mathrm{ONO}_{2}$, nitroxyl $\mathrm{RNO}^{\circ}$, phenoxyl, alcohoxile RCO, peroxyl $\mathrm{RCOO}^{\circ}$ the among other highly reactive polyunsaturated fatty acids in the membranes of cells producing the peroxyl radical primary product of lipid peroxidation in the presence of a reducing agent as hydroperoxide [48] whose decomposition gives rise to malondialdehyde and 4 hydroxy alquenal, Figure 5, that bind to $\mathrm{RSH}_{2}$ of the amino acids in proteins and DNA thymine which metal ions (trace elements) can lead to mutations [49].

When agents are an intense impact stressors and chronic natural antioxidant defenses of our body such as glutathione, vitamin $\mathrm{E}$ and superoxide dismutase are not able to neutralize excess free radicals as cell membranes are damaged severely. Oxidative stress can be measured by enzyme superoxide dismutase (SOD), lipoperoxidase (LP), uric acid and malondialdehyde (MDA) the major molecular markers of oxidative stress [50]. The antioxidant properties of uric acid have been studied recently, its plasma concentration is 10 times greater than vitamins $\mathrm{E}$ and $\mathrm{C}$ [51], its soluble form in plasma urate, captures the radical superoxide $\left({ }^{\circ} \mathrm{O}_{2}\right)$, hydroxyl radical $\left(\mathrm{HO}^{\circ}\right)$, inhibits

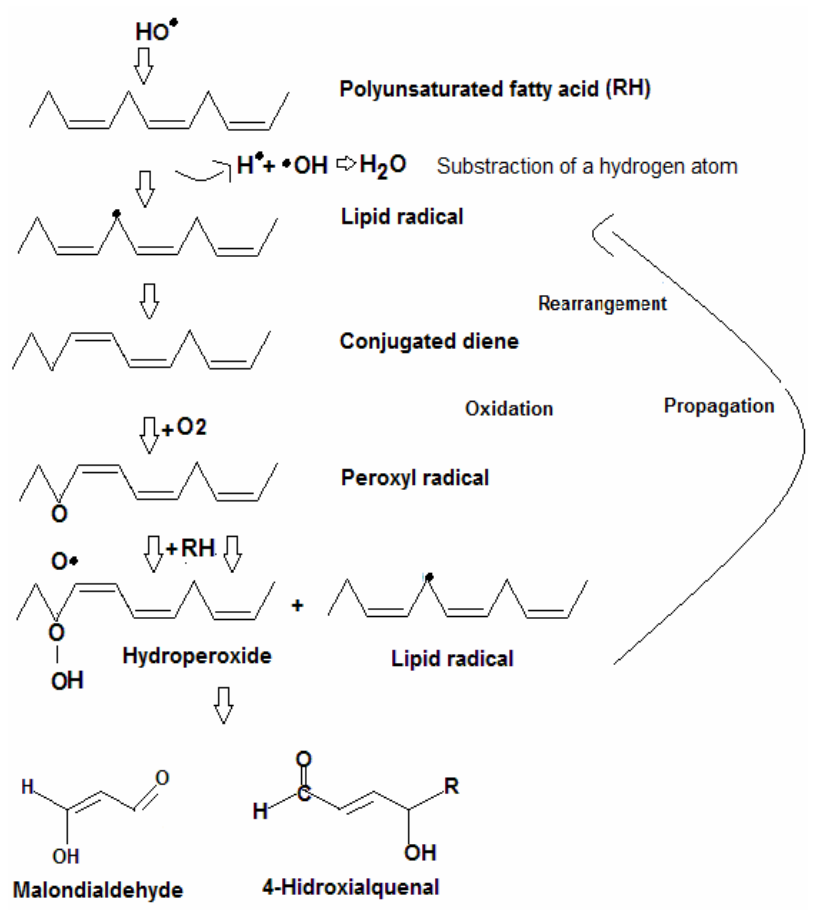

Figure 5. Lipoperoxidation of polyunsaturated fatty acids. The lipid peroxidation process involving free radicals superoxide $\left(\mathrm{O}_{2}^{\circ}\right)$ and hydroxyl $\left(\mathrm{OH}^{\circ}\right)$ this by reacting with the poly-insaturated fatty acid, lose a hydrogen atom in the presence of ${ }^{\circ} \mathrm{OH}$ radical produce a water and lipid radical. The main product of these process is the peroxyl that when its reduced forms hydroperoxyle, its decomposition forms malondial- dehyde and 4 hydroxialquenal. These substances are very reactives with $\mathrm{R}-\mathrm{SH} 2$ of proteins and with DNA thymine. the reaction of nitric oxide (NO) with $\mathrm{O}_{2}$ and prevents the formation of highly toxic peroxynitrite causes cell damage by nitration tyrosine residues of proteins. Uric acid, helps maintain normal levels of NO and endothelial function to prevent degradation of the enzyme superoxide dismutase extracellular enzyme that is essential in maintaining vascular endothelial function.

Oxidative stress induces excessive entry of free fatty acids to the liver where it is stored as triglycerides. This accumulation of lipids in the liver, the mitochondria contribute to losing the ability to oxidize fatty acids by $\beta$ oxidation and transported to the cytoplasm. In these circumstances the liver key organ in maintaining homeostasis, has transformed liver fat and there is a pathophysiological state known as steatohepatitis that develops fibrosis/cirrhosis and consequently the altered metabolism in peripheral organs: muscle, brain, heart, kidney and pancreas.

\section{Discussion}

To investigate the activity of a more comprehensive mix seemingly more difficult than when investigating an active substance or drug. However, this difficulty is partially resolved by the engagement of researchers bound in their respective areas of expertise assigned to different research centers and institutes and thus to ensure the feasibility of meeting the targets committed to projects resulting from the research. This criterion is necessary and required to perform more comprehensive investigation with the mixture of plants through two stages of research: the first basic research in animal models to demonstrate through pharmacological studies of acute and chronic sub 30 days that the mix of plants non-lethal effects or toxicity at the therapeutic dose given to continue the second phase of research in patients with clinical diagnosis of the disease. In conducting research in this manner, it is possible to scientifically validate the healing properties of plants of Traditional Medicine are potentially useful for effective and safe herbal therapies with significant impact on applied research. Of course, this implies strong support for the institutions concerned to promote the development of substantive programs that allow plants to obtain optimum crop quality in sufficient quantities and at appropriate times. Also promote the linking programs with health institutions to shape its application in clinical research projects and marketing to reach prospective new phytomedicines. Sinergistic effect is even greater when the plants are selected for their biological activity and physiochemical similar properties.

Since we now are getting to know the molecular mechanisms of activity of the plants investigated individually or combined to form blends achieved a syner- 
gistic effect on the activity of plants without producing toxic effects or at least reduce at minimum. The absence of toxicity should be evaluated experimentally before treatments in humans by identifying clinically relevant biochemical parameters, transaminases, triglycerides, cholesterol, glucose, bilirrubin, uric acid and total protein. In Mexico it is very clear trend for the acceptance of medicinal plants as the main resource of alternative medicine in institutes, universities and the National Medical Center, Mexican Institute of Social Security.

It is important to note that the empirical use of herbal preparations involves risk, improper use can pose a public health problem, and the greatest danger is when the plants are used indiscriminately. In this sense, many people wrongly believe that plants are safe and secure employments are to be of natural origin. There are often in hospitals with poisoning attributed to misuse of the plants, mainly due to the self limitation, lack of plant species used or the dose abuse it is necessary that herbal therapies are prescribed by professionals in the knowledge of plant use and monitor the effectiveness and safety of treatments.

There is growing interest in obtaining new plant products with quality and effective health care. To maximize the potential of herbal medicine in diseases and achieve better results when using phytomedicines, you should meet the following recommendations. Know very well the first plants to be used and preferably cut shortly before the end of blooming with strict adherence to appropriate procedures to obtain specimens in optimal conditions of quality. Second, immediately disinfected with $1 \%$ bleach, rinse with distilled water and transported carefully to the laboratory, prepare specimens for identification by botanical experts, third dehydrate the plants at $50^{\circ} \mathrm{C}$, micro-pulverized and combine it respect at the percentage at the proportions appropriate to form a mixture; encapsulate suitable quantities, stored in amber bottles and kept refrigerated sterile or room temperature if used in a recent.

\section{Conclusions}

Plants are an extraordinary remedy of nature by the wide variety of molecular structures in their constitution that can be used for different therapeutic procedures in chronic degenerative diseases such as type 2 Diabetes Mellitus (DM2), cirrhosis, cancer and obesity which are the greater health impact.

Today herbal preparations are used to combine plants in percentage proportions suitable for forming mixtures, the use of mixtures has important advantages, is achieved by a synergistic effect on the activity of interest also does not produce toxic effects or at least reduced to a maximum this is because the molecules are mixed, if not active in the desired effect, antagonizing the activity of other mole- cules that are also in the mix that might be causing to produce toxicity.

The strategy of using mixtures of micropulverized plants is a good choice because this microparticles behave as microreleasing systems, their constituents with great bioavailability to target cells without evidence of any signs of toxicity in subchronic 30 day treatment and thus is relevant propose that these preparations are feasible and effective for the control of various diseases.

\section{References}

[1] R. J. Gallardo, "Medicina Tradicional Purépecha," 1st Edition, El Colegio de Michoacán, Instituto Mexicano de Cultura AC, México, 2002.

[2] V. D. Waizel, "Las Plantas Medicinales y las Ciencias, Una Visión Multidisciplinaria,” 1st Edition, Instituto Politécnico Nacional, México, 2006.

[3] A. O. Hutterer, "La Medicina Tradicional Cuestionada: Antecedentes, Perspectivas y Prospectivas en México y Latinoamérica," 1st Edition, Extra Internacional de México S. A. de C. V., México, 2000.

[4] J. B. Calixto, "Twenty-Five Years of Research on Medicinal Plants in Latin America," Journal of Ethnopharmacology, Vol. 22, No. 100, 2005, pp. 131-134. doi:10.1016/j.jep.2005.06.004

[5] M. L. M. Beltran, A. M. P. Perez, A. G. Sanchez and L. H. Ruiz, "Male Rat Infertility Induction/Spermatozoa and Epididimal Plasma Abnormalities after Oral Administration of Kalanchoe gastonis Bonnieri Natural Juice," Phytotherapy Research, Vol. 17, No. 4, 2003, pp. 315-319. doi:10.1002/ptr.1131

[6] S. Mutalik, M. Chetana, B. Sulochana, P. Devi and N. Udupa, "Effect of Dianex, a Herbal Formulation on Experimentally Induced Diabetes Mellitus," Phytotherapy Research, Vol. 19, No. 5, 2005, pp. 409-415.

doi:10.1002/ptr.1570

[7] H. W. Hui, G. Tang and V. L. W. Go, "Hypoglycemic Herbs and Their Action Mechanisms," Chinese Medicine, Vol. 4, No. 11, 2009, pp. 11-21. doi:10.1186/1749-8546-4-11

[8] I. Shimizu, "Sho-Saiko-To Japanese Herbal Medicine for Protection against Hepatic Fibrosis and Carcinoma," Gastroenterology and Hepatology, Vol. 15, Supplement 1, 2000, pp. 84-90. doi:10.1046/j.1440-1746.2000.02138.x

[9] M. W. Baraka, "Herbal Compositon for Diabetes and Method of Treatment," US Patent No. 6042834, 28 March 2000.

[10] P. Chiereglin, "Farmacia Verde/Manual Práctico de Herboristeria,” 1st Edition, Madrid J. \& Madrid Cenzano, España, 2000.

[11] L. K. N. Okinea, "The Antidiabetic Activity of the Herbal Preparation ADD-199 in Mice: A Comparative Study with Two Oral Hypoglycaemic Drugs,” Journal of Ethnopharmacology, Vol. 97, No. 1, 2005, pp. 31-38. doi:10.1016/j.jep.2004.09.048 
[12] K. T. Leung, C. M. Lawrence and M. Chiu, “In Vitro Antiviral Chinese Medicinal Herbs against Duck Hepatitis B Virus,” Phytotherapy Research, Vol. 20, No. 10, 2006, pp. 911-914. doi:10.1002/ptr.1969

[13] R. L. Huacuja, V. A. L. López, A. Panduro, P. Mondragón and B. M. L. Miranda, "Fitoterapia de la Hepatitis Airal B Crónica,” Investigación en Salud, Vol. 9, No. 3, 2007, pp. 190-197.

[14] R.-L. Huang, Y.-L. Huang, J.-C. Ou, C.-C. Chen, F.-L. Hsu and C. M. Chang, "Screening of 25 Compounds Isolated from Phyllanthus Species for Antihuman Hepatitis B Virus in Vitro," Phytotherapy Research, Vol. 17, No. 5, 2003, pp. 449-453. doi:10.1002/ptr.1167

[15] G.-B. Yao, “Treatment of Chronic Hepatitis B in China," Journal of Gastroenterology and Hepatology, Vol. 15, Supplement 2, 2000, pp. E61-E66. doi:10.1046/j.1440-1746.2000.02106.X

[16] T. Mangena and N. Y. O. Muyima, "Comparative Evaluation of the Antimicrobial Activities of Essential Oil of Artemisa afra, Pteronia incana y Rosmarinus officinalis in Selected Bacteria and Yeast Strains," Letters in Applied Microbiology, Vol. 28, No. 4, 1999, pp. 291-296. doi:10.1046/j.1365-2672.1999.00525.x

[17] G. Rojas, J. Levaro and V. Tortoriello Navarro, “Antimicrobial Evaluation of Certain Plants Used in Mexican Traditional Medicine for the Treatment of Respiratory Diseases,” Journal of Ethnopharmacology, Vol. 74, No. 1, 2001, pp. 97-101. doi:10.1016/S0378-8741(00)00349-4

[18] A. T. Borchers, S. Sakay, G. L. Henderson, M. R. Harkey, C. L. Keen, J. S. Stern, K. Terasawa and M. E. Gershwin, "Shosaiko-To and Other Kampo (Japanese Herbal) Medicines: A Review of Their Inmunomodulatory Acti- vities," Journal of Ethnopharmacology, Vol. 73, No. 1-2, 2000, pp. 1-13. doi:10.1016/S0378-8741(00)00334-2

[19] M. K. Canales and B. M. Geller, "Surviving Breast Cancer. The Role of Complementary Therapies," Community Health, Vol. 26, No. 1, 2003, pp. 11-24.

[20] S. Gozum, A. Tezel and M. Koc, "Complementary Alternative Treatments Used by Patients with Cancer in Eastern Turkey," Cancer Nursing, Vol. 26, No. 3, 2003, pp. 230-236. doi:10.1097/00002820-200306000-00010

[21] L. Huacuja, A. M. Puebla, A. Carranco, M. L. Miranda, H. Merchant, A. Reyes and A. Guzman, "Contraceptive Effect on Male Rats after Administration of Kalanchoe blossfeldiana Crassulaceae Plant Aqueous Crude Extract,” Advanced Contraceptive Delivery Systems, Vol. 13, No. 1, 1997, pp. 13-21.

[22] B. M. L. Miranda, R. L. Huacuja, V. A. L. López and A. Panduro, "Fitoterapia Molecular Como Parte de la Medicina Alternativa Complementaria en las Enfer-Medades del Hígado,” Investigación en Salud, Vol. 7, 2005, pp. 64-70.

[23] R. Misha and O. Cohen, "Herbal Complementary and Alternative Medicine Therapies for Liver Disease," Clinical in Liver Disease, Vol. 5, No. 2, 2001, pp. 461-468.

[24] E. Speroni, R. Cervelallati and P. Govoni, "Efficacy of Different Cynara scolymus Preparations on Liver Complains,” Journal of Ethnopharmacology, Vol. 86, No. 2-3,
2003, pp. 203-211. doi:10.1016/S0378-8741(03)00076-X

[25] G. Shcmeda-Hirschmann and Y. Erdem, "Traditional Medicine and Gastroprotective Crude Drugs,” Journal of Ethnopharmacology, Vol. 100, No. 1-2, 2005, pp. 61-66. doi:10.1016/j.jep.2005.06.002

[26] A. M. Panico, V. Carkile and Y. Garuti, "Effect of Hyaluronic Acid and Polysacarides from Opuntia ficus indica (L) Cladodes on the Metabolism of Human Chondrocyte Cultures,” Journal of Ethnopharmacology, Vol. 111, No. 2, 2007, pp. 315-321. doi:10.1016/j.jep.2006.11.020

[27] H.-P. Guan, Y. Li, M. V. Jensen, C. B. Newgard, C. M. Steppan and M. A. Lazar, "A Futile Metabolic Cycle Activated in Adipocytes by Antidiabetic Agents," Nature Medicine, Vol. 8, No. 10, 2002, pp. 1122-1128. doi:10.1038/nm780

[28] W. L. Li, H. C. Zheng, J. Bukuru and N. De Kimpe, "Natural Medicines Used in the Traditional Chinese Medical System for Therapy of Diabetes Mellitus,” Journal of Ethnopharmacology, Vol. 94, No. 1, 2004, pp. 1-21. doi:10.1016/j.jep.2003.12.031

[29] V. Vats, J. K. Grover and S. S. Rathi, "Evaluation of Anti-Hyperglycemic and Hypoglucemic Effect of Trigonella foenum-graecum Lin, Ocinum sanctum Lin and Pterocarpus marsupium in Normal and Alloxanized Diabetics Rats," Journal of Ethnopharmacology, Vol. 79, No. 1, 2002, pp. 95-100. doi:10.1016/S0378-8741(01)00374-9

[30] S. M. Downer, M. M. Cody and P. McCluskey, "Pursuit and Practice of Complementary Therapies by Cancer Patients Receiving Conventional Treatment," British Medical Journal, Vol. 309, 1994, pp. 86-89.

[31] E. Ernst and S. R. Casillech, "The Prevalence of Complementary/Alternative Medicine in Cancer: A Systematic Review," Cancer, Vol. 8, No. 4, 1998, pp. 10-15.

[32] A. Y. Oubre, T. J. Carlson, S. R. King and G. M. Reaven, "From Plant to Patient and Ethnomedical Approach to the Identification of New Drugs for the Treatment of NIDDM,” Diabetologia, Vol. 40, No. 5, 1997, pp. 614617.

[33] S. E. Inzuchi, "Oral Antihyperglycemic Therapy for Type 2 Diabetes/Scientific Review," The Journal of the American Medical Association, Vol. 287, No. 3, 2002, pp. 360-372.

[34] N. Morral, "Novel Targets and Therapeutic Strategies for Type 2 Diabetes," Trends in Endocrinology and Metabolism, Vol. 14, No. 4, 2003, pp. 169-175. doi:10.1016/S1043-2760(03)00031-6

[35] L. D. May, J. H. Leftorowitch M. T. Kram and D. E. Rubin, "Mixed Hepatocelular Cholestatic Liver Injury after Pioglitazone Therapy,” Annals of Internal Medicine, Vol. 136, No. 6, 2002, pp. 449-452.

[36] J. Lieu, “Oleanolic Acid: Research Perspectives,” Journal of Ethnopharmacology, Vol. 100, No. 1-2, 2005, pp. 92-94. doi:10.1016/j.jep.2005.05.024

[37] A. Matzumoto, Y. Matsukawa and T. Suzuki, “The Polymer Allows Method as a New Preparation Method of Biodegradable Microspheres: Principle and Applications 
to Cisplatin Loaded Microspheres," Journal of Controlled Release, Vol. 48, No. 1, 1997, pp. 19-27. doi:10.1016/S0168-3659(97)00031-X

[38] M. Yokohama, M. Miyauchi, N. Yamada, T. Okano, Y. Sakurai, K. Kataa and S. Inoue, "Characterization and Anticancer Activity of the Michelle-Formi Polymeric Anticancer Drug Adramycin-Conjugated Poly (Ethylenglicol)-poly(aspartic acid) Block Copolymer," Cancer Research, Vol. 15, No. 50, 1990, pp. 1693-1700.

[39] N. Nishiyama, S. Okasaki and H. Cabral, "Novel Cisplatin-Incorporated Polymeric Micelles Can Eradicate Solid Tumors in Mice,” Cancer Research, Vol. 63, No. 24, 2003, pp. 8977-8983.

[40] A. Kumiko, Y. Masako and M. Tatzuya, "Carbon Nanohom as Anticancer Drugs Carriers,” Molecular Pharmacology, Vol. 2, No. 6, 2005, pp. 475-480. doi:10.1021/mp0500566

[41] L. Zhang, M. John and W. Q. Strong, "Scientific Perspectives and Drug Transporters and Their Role in Drug Interactions," Molecular Pharmacology, Vol. 3, No. 1, 2006, pp. 62-69. doi:10.1021/mp050095h

[42] E. Lugo Estrada, “Observaciones Clínicas de Plantas Medicinales en Diabetes,” 2nd Edition, Universidad Autónoma Chapingo, Chaopingo, 1999.

[43] V. Lassara and M. R. Palace, "Diabetes and Advanced Glycation and Products,” Journal of Internal Medicine, Vol. 251, No. 2, 2002, pp. 87-101.

[44] X. Miaomiao, H. Chunxu and T. Haiteng, “Antioxidant and Antiglycation Properties of Total Saponins Extracted from Traditional Chinese Medicine Used to Treat Diabetes Mellitus,” Phytotherapy Research, Vol. 22, No. 2,
2007, pp. 228-237.

[45] J. I. Sotelo-Felix, D. Martinez-Fong and P. Muriel de la Torre, "Protective Effect of Carnosol on CCl4 Induced Acute Liver Damage Rats," European Journal of Gastroenterology \& Hepatology, Vol. 14, No. 9, 2002, pp. 1001-1006. doi:10.1097/00042737-200209000-00011

[46] C. Kuklinsky, "Farmacognosia/Estudio de las Drogas y Sustancias Medicamentosas de Origen Natural," 1st Edition, Omega Ediciones, Barcelona, 2000.

[47] A. Andrade-Cetto and M. Heinrich, "Mexican Plants with Hipoglycaemic Effect Used in the Treatment of Diabetes," Journal of Ethnopharmacology, Vol. 99, No. 3, 2005, pp. 325-348. doi:10.1016/j.jep.2005.04.019

[48] A. Medina Navarro and J. J. Hicks Gomez, "Radicales Libres de Oxigeno," In: J. J. Hicks-Gomez, Ed., Bioquimica Inorganica y Biomedicina, Interamericana McGraw Hill, Mexico City, 2000, pp. 970-910.

[49] J. Bland, "Biochemical Consequences of Lipid Peroxidation,” Journal of Medical Education, Vol. 55, No. 3, 1978, pp. 151-155.

[50] L.-Q. Tang, W. Wei, L.-M. Chen and S. Liu, "Effects of Berberine on Diabetes Induced by Alloxan and a HighFat/High-Cholesterol Diet in Rats," Journal of Ethnopharmacology, Vol. 108, No. 1, 2006, pp. 109-115. doi:10.1016/j.jep.2006.04.019

[51] A. Chamorro, V. Obach, A. Cervera, M. Revilla, R. Deulofeu and J. H. Aponte, "Pronositic Significance of Uronic Acid Serum Concentration in Patients with Acute Ischemic Stroke,” Stroke, Vol. 33, No. 4, 2002, pp. 10481052. 